\title{
AN AHP, ANP DECISION SUPPORT APPROACH FOR THE PRIORITISATION AND SELECTION OF "RESTORATION" AND "IMPROVEMENT" PROJECTS WITHIN AN INDUSTRIAL ENVIRONMENT \\ Jean Khalil, Department of Mechanical Engineering \\ Arab Academy for Science Technology and Maritime transport, Cairo - Egypt \\ E-mail: Jean.Khalil@aast.edu
}

\begin{abstract}
In industry, rather commonly, and especially in developing countries and indeed when financial crises persist, it becomes hard to convince the decision takers of an organization to invest in "restoration" or "improvement" projects within: their infrastructure, their equipment or their methods of function. But the fact is, ceasing to perform "restoration" or "improvement" projects are like a patient who stops taking his/her medication, a direct way of slow suicide. Even if the managers are convinced with this fact, they face the traditional difficulty of selection or deferral of projects; as well as the difficulty of deciding on the amounts and the proportions of expenditures on these projects. To the best of the author's knowledge, this problem has never been discussed in literature before. This paper proposes a solution approach through the implementation of the AHP and the ANP to help the decision taker, compose an objective decision on: the selection and the expenditure amounts of "restoration" and "improvements" projects within their domain. The Hierarchy or the network is built based on the relevant criteria as deduced from actuality in industry. The judgments are input by experts from the industry. The user conducts the judgments for alternatives once a year, and therefore gets a measurable output of the organization's interest in realizing the projects subject of the discussion. This output is therefore translated into selection and trend of expenditures. One major characteristic of the proposed approach is that it takes in consideration the surrounding conditions through the user judgments and therefore evolves with the organization. The implementation of this approach is expected to preserve vast investments from deterioration or collapse, guarantees the continuous improvements to take place and as importantly prevents subjective conflicts over requirements of expenditures.
\end{abstract}

Keywords: Decision support, selection, prioritization, restoration and improvement projects.

\section{Introduction}

Based on the author's link with industry and the corporate world, the following common problem arose especially in developing countries and specifically at times of recession. The managers lack enthusiasm to spend money on restoration projects or on upgrade and improvement projects. In consequence, the available infrastructure and equipment age and deteriorate while the methods of function get solidified at a standstill state. The author may be particularly concerned with the maintenance departments but the problem also exists in every department including the production lines. On the psychological side, the disregard of these projects being personal unsupported decisions cause frustration and loss of interest to the people. What increases the frustration is that the decision taker does not challenge the positivity of the projects or even their necessity, but the nonscientific 
IJAHP Article: Khalil/Paper Proposal To Be Submitted to the International Symposium of the Analytic Hierarchy Process 2014, Washington D.C., U.S.A.

mechanism of decision making prevents most managers from taking the costly decision of projects realization. The solution of this problem is supposed not only to preserve the investment of the organization but also and may be as importantly to preserve one of the most important sources of steam generation within the production cycle, namely workforce motivation.

In the rest of this paper the term project stands for "a project suggested by personnel within the organization which consists of either: 1- restoring a module, like overhauling a set of two worn out vertical hydraulic jacks in the mechanical workshop, or 2improving an existing function like replacing paper based fault reports and work orders by a central computerized system with remote access points in shop floors".

\section{Literature Review}

In Literature, the AHP and the ANP have been implemented frequently for the solution of problems that share common ground with the problem under consideration. (Shaw et al 2012) used FAHP in the selection of suppliers based on the traditional criteria but redefined the selection with the consideration of carbon emission as a crucial criterion for environmental preservation. (Vidal, Marle and Bocquet 2011) combined Delphi process with the AHP in order to define a measure for projects complexity expressed as relative weights and the inner sources of this complexity. (Wey and Wu) 2007 used ANP with goal programming for the selection of transportation infrastructure projects and therefore the allocation of resources. On the other hand, researchers frequently stress on the fact that quantifying qualitative judgments is a job that risks inaccuracy and involves miscalculations of results, for that problem (Hefny, Elsayed and Aly 2011) and (Pedrycz and Song 2014) suggested linguistic refining to allow fuzziness inclusion within the crisp judgments numbers. From this brief presentation, it may be deduced that the specific area subject of the study has not been covered in literature but, related work helped in formulating the required outcome of this paper as follows. This work aims at weighing the suggested projects in a scientific manner through the AHP and the ANP and therefore to supply a scientific ground for prioritization and selection or deferment of projects.

\section{Hypotheses/Objectives}

The objective of this paper is to develop a model that would act as a decision support tool for the decision takers in industry and the corporate world. This tool is designed to help the decision taker(s) to prioritize, select and direct funds towards the suggested projects. This job is supposed to happen at the beginning of every financial year therefore, to set the plan of restoration and improvement clear for everyone and to eliminate conflicts, through its scientific and professional basis. A group of relevant people in industry agreed on an average of $11 \%$ of the net profit to be spent on the considered type of projects, the rest of this paper answers the question: How should this sum be invested ?

\section{Research Design/Methodology}

The developed model in this study is the result of many situations where the personnel of an organization had suggestions of projects and when discussed with decision takers in presence of the authors were rejected on a single personal judgment ground. On the opposite side, other projects were put in place only and only because the decision taker believed they are useful while the personnel who are actually supposed to use them 
IJAHP Article: Khalil/Paper Proposal To Be Submitted to the International Symposium of the Analytic Hierarchy Process 2014, Washington D.C., U.S.A.

challenged their necessity and had alternatives in mind. The problem here is NOT a communication problem. As witnessed by the author, the problem is: a "lack of prioritization", "selection" and "direction of expenditures" mechanism. To solve this problem, the suggested approach would start before the beginning of the financial year by asking relevant personnel within the organization to suggest projects and to study their overall costs. The list of suggested projects will then compose the list of alternatives which will be fed into the AHP or the ANP model in order to find out the weight of each project either relative or absolute depending upon whether a classical or a ratings model is used. The structures of the Hierarchy and the network are the result of extensive discussion between relevant personnel, they are however flexible, which means that every organization is free to tailor the hierarchy or the network to what suits its own nature. The mechanism of judgments conductance and consistency assurance is further explained in section 5 .

\section{Data/Model Analysis}

This section shows the actual structure of both AHP and ANP models as suggested by the author.

\subsection{The Hierarchy}

The goal level: The prioritization of projects based on the welfare of the organization.

The criteria level: Within the piloting model that is developed in this paper, it consists of the following criteria

- $\quad$ Effect on work efficiency.

- Effect on personnel satisfaction.

- Effect on the organization prestige.

- Risk of temporary work disturbance.

- Percentage of cost to the total available fund (this particular criterion would make use of the ANP advantage over the AHP in the acquisition of personnel true believes).

The alternatives level: The suggested projects.

\subsection{The Network}

Unlike the AHP model, the ANP model has no goal but the mechanism of the network allows feedback through the judgments of criteria with respect to alternatives.

\subsection{A practical study}

The structure of the model was suggested to the relevant personnel within a medium size factory specialized in Hydraulic and Pneumatic systems. They cut down the significant criteria of judgment to the following four.

1- The cost of the project.

2- The period of realization.

3- The financial payback to the organization.

4- The personnel motivation and satisfaction.

For the sake of practicality within this paper, the originally suggested projects were reduced to the here presented three projects, were the concept may well be explained and then the model may be repeated for any number of projects. 
IJAHP Article: Khalil/Paper Proposal To Be Submitted to the International Symposium of the Analytic Hierarchy Process 2014, Washington D.C., U.S.A.

1- The commissioning, set up and implementation of an Enterprise Resources Program (ERP).

2- The commissioning and set up of an automated attendance system with finger-print recognition.

3- The Restoration and improvement of the refectory area.

The clusters and the nodes of the AHP and the ANP models are shown in figure 1 and 2 show respectively.

Concerning the judgments entry, the author takes one of two approaches; either a group of experts conduct a meeting like a think tank where they discuss judgment by judgment and achieve a reply to each pairwise
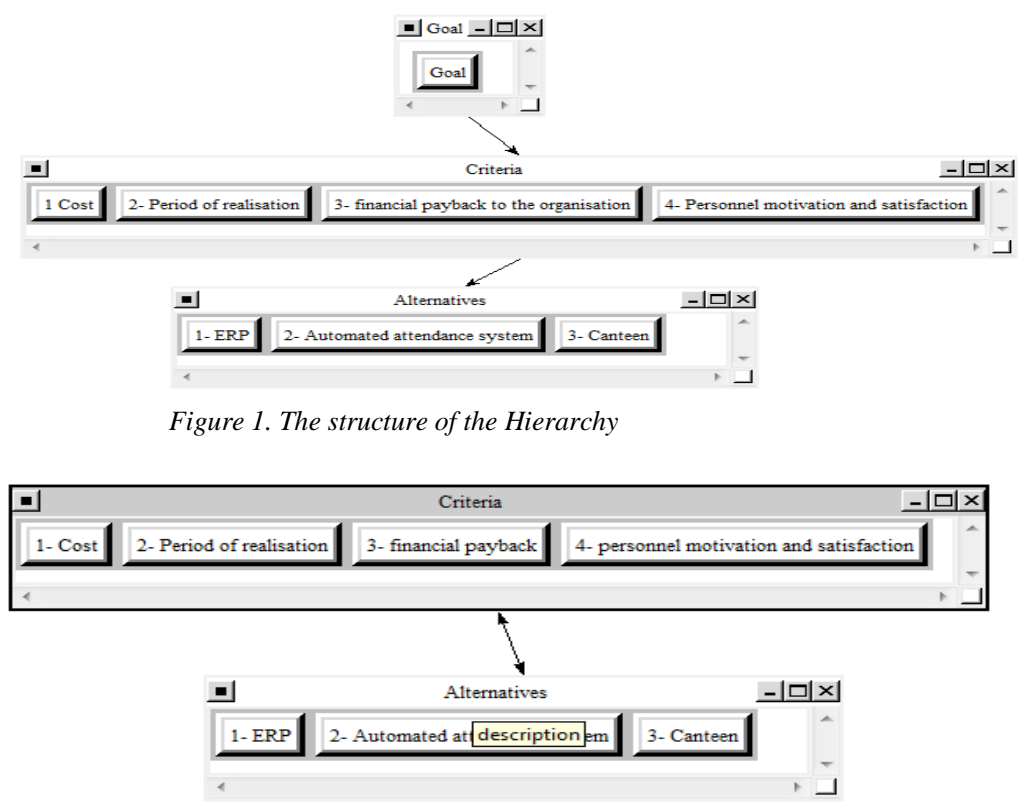

Figure 2. The structure of the Network comparison; or the author performs all the comparisons with every expert separately and then normalizes the replies statistically. It is necessary to highlight in this section that every effort is done to make the comparisons linguistically clearer and to help the expert perform their judgments accurately. In the practical study, the first approach was taken. Figure 3 and 4 show the matrices of judgments for the AHP and the ANP respectively. Given the measures of improvement of the human pairwise judgment process, the inconsistency ratio in both the Hierarchy and the Network was well below 0.1 .

\begin{tabular}{|c|c|c|c|c|c|c|c|c|c|}
\hline \multicolumn{10}{|c|}{ DUper Decisions Main Window: KEFAC- PrjetSIctn - AHP - Jan -14.sdmod: Unweighted Super Matrix } \\
\hline & \multirow{2}{*}{$\begin{array}{l}\text { Cluster } \\
\text { Nodee } \\
\text { Labeis }\end{array}$} & \multicolumn{3}{|c|}{\begin{tabular}{|c|} 
Alternatives \\
\end{tabular}} & \multicolumn{4}{|c|}{ Criteria } & \multirow{2}{*}{\begin{tabular}{|l|} 
Goal \\
Goal \\
\end{tabular}} \\
\hline & & \multirow{2}{*}{\begin{tabular}{|l|}
1 - ERP \\
0.000000 \\
\end{tabular}} & \multirow{2}{*}{$\begin{array}{c}\begin{array}{c}\text { 2-Automated } \\
\text { attendance system }\end{array} \\
0.000000 \\
\end{array}$} & \multirow{2}{*}{$\begin{array}{l}\text { 3- } \\
\text { Canteen } \\
0.000000 \\
\end{array}$} & \multirow{2}{*}{\begin{tabular}{|l|}
1 Cost \\
0.869540 \\
\end{tabular}} & \multirow{2}{*}{$\begin{array}{l}\text { 2- Period of } \\
\text { realisation }\end{array}$} & \multirow{2}{*}{$\begin{array}{c}\text { 3- financial payback } \\
\text { to the organisation } \\
0.758280 \\
\end{array}$} & \multirow{2}{*}{$\begin{array}{l}\text { 4- Personnel } \\
\text { motivation and } \\
\text { satisfaction }\end{array}$} & \\
\hline \multirow{3}{*}{$\begin{array}{l}\text { Alterna } \\
\text { tives }\end{array}$} & 1- ERP & & & & & & & & 0.000000 \\
\hline & $\begin{array}{l}\text { 2-Automated } \\
\text { attendance system }\end{array}$ & 0.000000 & 0.000000 & 0.000000 & 0.130431 & 0.065000 & 0.166932 & 0.059916 & 0.000000 \\
\hline & $\begin{array}{l}3- \\
\text { Canteen }\end{array}$ & 0.000000 & 0.000000 & 0.000000 & 0.000029 & 0.064731 & 0.074788 & 0.749294 & 0.000000 \\
\hline \multirow{4}{*}{ Criteri } & 1 Cost & 0.000000 & 0.000000 & 0.000000 & 0.000000 & 0.000000 & 0.000000 & 0.000000 & 0.217871 \\
\hline & $\begin{array}{l}\text { 2- Period of } \\
\text { realisation }\end{array}$ & 0.000000 & 0.000000 & 0.000000 & 0.000000 & 0.000000 & 0.000000 & 0.000000 & 0.050621 \\
\hline & $\begin{array}{l}\text { 3- financial payback } \\
\text { to the organisation }\end{array}$ & 0.000000 & 0.000000 & 0.000000 & 0.000000 & 0.000000 & 0.000000 & 0.000000 & 0.306220 \\
\hline & $\begin{array}{l}\text { 4-Personnel } \\
\text { motivation and } \\
\text { satisfaction }\end{array}$ & 0.000000 & 0.000000 & 0.000000 & 0.000000 & 0.000000 & 0.000000 & 0.000000 & 0.425289 \\
\hline Goal & Goal & 0.000000 & 0.000000 & 0.000000 & 0.000000 & 0.000000 & 0.000000 & 0.000000 & 0.000000 \\
\hline \multicolumn{10}{|c|}{ Done } \\
\hline
\end{tabular}

Figure 3. The supermatrix for the Hieraarchy

\begin{tabular}{|c|c|c|c|c|c|c|c|c|}
\hline \multicolumn{8}{|c|}{ D Super Decisions Main Window: KEFAC- PrjctSletm - ANP - Jan -14.sdmod: Unweighted Super Matrix } & \multirow[t]{2}{*}{ 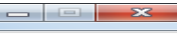 } \\
\hline & \multirow{2}{*}{$\begin{array}{l}\text { Cluster } \\
\text { Noode } \\
\text { Labels }\end{array}$} & \multicolumn{3}{|c|}{ Alternatiwes } & \multicolumn{3}{|c|}{ Criteria } & \\
\hline & & 1- ERP & $\begin{array}{l}\text { 2- Automated } \\
\text { attendance system }\end{array}$ & Canteen & $1-$ cost & $\begin{array}{l}\text { 2- Period of } \\
\text { realisation }\end{array}$ & $\begin{array}{l}\text { 3-financial } \\
\text { payback }\end{array}$ & $\begin{array}{l}\text { 4-personnel } \\
\text { motivation and } \\
\text { satisfaction }\end{array}$ \\
\hline \multirow{3}{*}{$\begin{array}{l}\text { Alterna } \\
\text { tives }\end{array}$} & 1- ERP & 0.000000 & 0.000000 & 0.000000 & 0.571429 & 0.911393 & 0.755222 & 0.189903 \\
\hline & $\begin{array}{l}\text { 2-Automated } \\
\text { atterionce system }\end{array}$ & 0.000000 & 0.000000 & 0.000000 & 0.085714 & 0.037975 & 0.172408 & 0.059816 \\
\hline & $\begin{array}{l}\text { 3- } \\
\text { Canteen }\end{array}$ & 0.000000 & 0.000000 & 0.000000 & 0.342857 & 0.050632 & 0.072369 & 0.750282 \\
\hline \multirow{4}{*}{ Criteri } & 1 - Cost & 0.317702 & 0.257592 & 0.634310 & 0.0000000 & 0.000000 & 0.0000000 & 0.000000 \\
\hline & $\begin{array}{l}\text { 2- Period of } \\
\text { realisation }\end{array}$ & 0.084387 & 0.085027 & 0.058992 & 0.oooooo & o.ooaaao & o.oobiaio & 0.000000 \\
\hline & $\begin{array}{l}\text { 3- financial } \\
\text { paybaack }\end{array}$ & 0.406689 & 0.572243 & 0.070940 & o.oooooo & o.oooooo & o.oooooo & 0.000000 \\
\hline & $\begin{array}{l}\text { 4-personnel } \\
\text { motivation and } \\
\text { satisfaction }\end{array}$ & 0.191222 & 0.085138 & 0.235758 & o.coooooo & 0.0000000 & o.ooonaoo & 0.0000000 \\
\hline \multicolumn{9}{|c|}{ Done } \\
\hline
\end{tabular}

International Symposium of

Figure 4. The supermatix for the Network

the Analytic Hierarchy

4

Washington, D. C.

Process

June 29 - July 2, 2014 
IJAHP Article: Khalil/Paper Proposal To Be Submitted to the International Symposium of the Analytic Hierarchy Process 2014, Washington D.C., U.S.A.

This proposal presents only classical AHP and ANP models, but the idea may be extended to ratings models in which case, intensities are allocated under each criterion and an infinite number of projects (alternatives) may be considered and absolute weights are given for the projects instead of relative weights. In Both cases the realization of projects should be performed on a descending order of weights within the budget limits.

\section{Limitations}

The model subject of this paper is developed for projects of normal size and which fall in the grey area between the "must be done" and "not required". It cannot be used as a decision support tool in the case of a major projects like the renovation of a whole production line or the restoration of the headquarter building for example. The model also is not useful for small projects where the amount of expenditure is not significant to the organization. In order to improve the accuracy of the judgments, the user may be given the essence of the pairwise comparisons in a questionnaire form and he/she should be allowed a few days to reflect on them, then the model should be executed once and reexecuted anew two days later.

\section{Conclusions}

The here developed work is expected to move one more sector of the corporate life from chaos to systemization. As per the author's experience, a major source of organization's stand still or even deterioration may be annihilated through the power of AHP / ANP in turning the intangible into undebatable decisions. The approach requires reasonable efforts in building the hierarchy and the network and in performing the required judgments through industrial expertise. However, once accomplished, the implementation of the model by the user requires even less efforts.

\section{Key References}

Hefny, H. A., ElSayed, H. M., \& Aly, H. F. (2013). Fuzzy multi-criteria decision making model for different scenarios of electrical power generation in Egypt. Egyptian Informatics Journal 14, $125-133$.

Pedrycz, W., \& Song, M. (2014). A granulation of linguistic information in AHP decision-making problems. Information Fusion 17, 93 - 101.

Shaw, K., Shankar, R., Yadav, S., \& Thakur, L. S. (2012). Supplier selection using fuzzy AHP and fuzzy multi-objective linear programming for developing low carbon supply chain. Expert systems with applications 39, 8182 - 8192.

Vidal, L., Marle, F., \& Bocquet J. (2011). Using a Delphi process and the Analytical Hierarchy Process (AHP) to evaluate the complexity of projects. Expert Systems with applications 38, $5388-5405$.

Wey, W., \& Wu, K (2007). Using ANP priorities with goal programming in resource allocation in transportation. Mathematical and Computer Modelling 46, 985 - 1000. 